Зінченко С. В., молодший науковий співробітник

Інститут овочівництва і баштанництва НААН

\title{
ЛЕЖКІСТЬ ПЛОДІВ БАКЛАЖАНА ЗАЛЕЖНО ВІД УМОВ ЗБЕРІГАННЯ
}

\section{Рецензент - кандидат сільськогосподарських наук Н. П. Куракса}

Наведено результати досліджень щуодо лежкості плодів баклажана різних підвидів та сортотипів, щуо зберігалися в різних умовах і видах упаковки. Виявлено умови зберігання баклажана, щуо забезпечують найменші природні втрати маси плодів та більиий вихід стандартної продукиії. Вивчено вплив способів зберігання плодів баклажана різних підвидів та сортотипів на їх хімічний склад після кожного терміну зберігання. Доведено ефективність використання різних видів упаковки та умов зберігання для конкретного дослідного сорту.

Ключові слова: плоди баклажана, сортотипи, підвид, зберігання, упаковка, умови.

Постановка проблеми. Для задоволення потреб населення в овочевій продукції необхідно не тільки збільшувати їі виробництво, а й домогтися рівномірного постачання овочів споживачу в відповідному сортименті за рахунок поєднання розвитку овочівництва та зберігання. Сезон дозрівання плодів баклажана та їх переробка співпадають зі строками дозрівання й переробкою інших овочів. Переробні підприємства не встигають переробляти всі овочі одночасно за сезон, тому питання зберігання сировини залишається наразі досить актуальним. На сьогодні недостатньо вирішена проблема зберігання плодів баклажана. Період споживання свіжих плодів баклажана - 40-50 днів на рік. Основний спосіб подовження терміну споживання населенням - це зберігання і переробка.

Аналіз основних досліджень і публікацій, у яких започатковано розв'язання проблеми. Серед робіт по умовах зберігання плодів баклажана багато суперечливих даних. Рекомендована температура коливається від $+1 \ldots+2$ до $+10{ }^{0} \mathrm{C}$, відносна вологість - від 80 до $100 \%$, строки зберігання - від двох тижнів до двох місяців (Ф. М. Білянський, Є. Я. Бардах, М. В. Тухшнайд, 1938; Д. Б. Рютов, 1970; С. І. Іванова, 1975; П.Ф. Сокол, 1978; Е. Е. Шахбазова, 1981; Ю. Г. Скорікова, 1982; В. П. Панченко, С. І. Іванова, 1983; В. В. Степанович, Б. В. Кошарницький, 1984). Різні результати одержані тому, що досліджувались різні сорти, вирощені в різних кліматичних i агротехнічних умовах. Автори звертали увагу на фізіологічний стан, зміни хімічного складу залежні від початкового хімічного складу плодів баклажана і впливу на них факторів зберігання.

Причинами значних втрат у процесі зберігання плодів $€$ недосконала технологія сортування за ступенем стиглості, різносортиці, недотримання строків і способу збирання урожаю, диференційовані температурно-вологі режими зберігання, попереднє охолодження в залежності від фізіологічного стану і т. д. Не вирішене до кінця й питання упаковки плодів із використанням полімерної упаковки. Із цих причин після двох-чотирьох діб плоди баклажана потрапляють у торгівельну мережу на 50-60 \% нестандартними [3].

Мета роботи - визначити мінливість показника лежкості та оптимальні умови зберігання плодів баклажана в залежності від підвиду та сортотипу.

Методика досліджень. Науково-дослідну роботу ву 2009-2010 рр. проводили з рослинами баклажана двох підвидів трьох сортів.

До західно-азіатського підвиду належать сорти:

1. Алмаз - середньостиглий, плід циліндричний, темно-фіолетового кольору. Кущ напіврозлогий, середньорослий.

2. Біла Лілія - середньоранній. Плід циліндричний, білого кольору. Кущ напіврозлогий, середньорослий.

До східно-азіатського підвиду - середньостиглий сорт Сауран. Плід грушовидний, темнофіолетового кольору. Кущ низькорослий, добре розгалужений [2].

Для зберігання брали свіжі, цілі, здорові плоди баклажана одного ботанічного сорту, однорідні за розміром, технічного ступеню стиглості плоди баклажана згідно з вимогами ДСТУ 266094 «Баклажани свіжі. Технічні умови» [1]. Зберігали їх в овочесховищі з природною вентиляцією, з відносною вологістю повітря 85-90\% та в холодильній камері за температури $+3 \ldots+4{ }^{0} \mathrm{C}$, iз відносною вологістю повітря 90-95 \%.

Плоди баклажана укладали у ящики № 3 (згідно з ГОСТ 13359 щільними рядами, в рівень із краями тари (контроль), а також у перфоровані 
поліетиленові пакети 3 отворами діаметром 2,0-5,0 см місткістю 5-6 кг, не щільно зав'язані. Кожні 10 діб дослідні зразки знімали зі зберігання, визначали кількість хворих плодів, вихід товарної продукції, природні втрати маси та їх хімічний склад після кожного терміну зберігання.

Результати досліджень. Нами встановлено, що плоди баклажана різних сортотипів мають різну лежкоздатність, яка залежить від сорту, кольору плоду, хімічного складу, виду упаковки та умов зберігання (табл. 1).

Після десяти діб зберігання найбільший вихід стандартної продукції був у холодильній камері в перфорованому поліетиленовому пакеті у сорту Алмаз (96,6 \%), із природною втратою маси 0,4 \%. За зберігання плодів в умовах овочесховища вищий вихід стандартної продукції також у перфорованому поліетиленовому пакеті сорт Біла Лілія (92,2 \%), із природною втратою маси 1,3\%.

Після двадцяти діб зберігання кращим варіантом із виходу стандартної продукції $є$ сорт Біла Лілія, що зберігали в умовах овочесховища в дерев'яних ящиках (79,0 \%), природна втрата маси 12,7 \%. Зберігання плодів баклажана в умовах холодильної камери в перфорованому поліетиленовому пакеті дало змогу отримати вихід стандартної продукції 78,7 \% (сорт Алмаз), із природною втратою маси 4,3\%.

Використання поліетиленової упаковки дало можливість значно знизити природну втрату маси плодів баклажана при зберіганні в умовах холодильної камери протягом двадцяти діб.
При зберіганні плодів сорту Біла Лілія в умовах холодильної камери спостерігалось ураження плодів хворобами незалежно від виду упаковки. Як відомо з літературних джерел, наявність антоціану в верхніх пагонах та опушенні листя підвищує холодостійкість рослин баклажана при вирощуванні в відкритому грунті, тому можемо припустити, що антоціанове забарвлення плоду також впливає на їх лежкість при низьких позитивних температурах. Сорт Біла Лілія немає антоціанового забарвлення плоду (колір плоду білий), тому зберігання в холодильній камері для даного сорту небажане.

Хімічний склад плодів баклажана визначався відразу після збирання і зберігання. Як показали наші дослідження, існує тісна залежність між вмістом основних хімічних речовин у плодах баклажана та умовами зберігання (табл. 2).

У середньому за два роки досліджень у плодах баклажана перед зберіганням вміст сухих речовин становив 8,92\% (сорт Алмаз), 9,49\% (сорт Сауран) та 9,91 \% (сорт Біла Лілія), вміст загального цукру, відповідно, 2,84 \%, 2,97 \% та 2,84\%.

Вміст аскорбінової кислоти знаходився в межах 2,36-2,77 мг/100 г, залишкова кількість нітратів не перевищувала допустимі рівні (ІДК - не більше 200 мг/кг).

Найбільші втрати сухих речовин, загального цукру та аскорбінової кислоти у плодах відмічено у перші 10 діб за умов їх зберігання у холодильній камері.

\section{1. Вихід товарної продукції та природні втрати маси плодів баклажсана різних сортотипів} після зберігання, (середнє за 2009-2010 рр.), \%

\begin{tabular}{|c|c|c|c|c|c|c|c|c|c|c|c|c|}
\hline \multirow{4}{*}{$\begin{array}{c}\text { Умови та види } \\
\text { тари }\end{array}$} & \multicolumn{6}{|c|}{ Західно-азіатський підвид } & \multicolumn{6}{|c|}{ Східно-азіатський підвид } \\
\hline & \multicolumn{4}{|c|}{ сорт Алмаз } & \multicolumn{4}{|c|}{ сорт Біла Лілія } & \multicolumn{4}{|c|}{ сорт Сауран } \\
\hline & \multicolumn{2}{|c|}{$\begin{array}{c}\text { овоче- } \\
\text { сховище }\end{array}$} & \multicolumn{2}{|c|}{$\begin{array}{c}\text { холодильна } \\
\text { камера }\end{array}$} & \multicolumn{2}{|c|}{$\begin{array}{c}\text { овоче- } \\
\text { сховище }\end{array}$} & \multicolumn{2}{|c|}{$\begin{array}{c}\text { холодильна } \\
\text { камера }\end{array}$} & \multicolumn{2}{|c|}{$\begin{array}{c}\text { овоче- } \\
\text { сховище }\end{array}$} & \multicolumn{2}{|c|}{$\begin{array}{c}\text { холодильна } \\
\text { камера }\end{array}$} \\
\hline & $\begin{array}{l}\text { ящик } \\
\text { (конт- } \\
\text { роль) }\end{array}$ & $\begin{array}{c}\text { пle } \\
\text { пакет }\end{array}$ & $\begin{array}{l}\text { ящик } \\
\text { (конт- } \\
\text { роль) }\end{array}$ & $\begin{array}{c}\text { пle } \\
\text { пакет }\end{array}$ & $\begin{array}{l}\text { ящик } \\
\text { (конт- } \\
\text { роль) }\end{array}$ & $\begin{array}{c}\text { пle } \\
\text { пакет }\end{array}$ & $\begin{array}{c}\text { ящик } \\
\text { (конт- } \\
\text { роль) }\end{array}$ & $\begin{array}{c}\text { пle } \\
\text { пакет }\end{array}$ & $\begin{array}{l}\text { ящик } \\
\text { (конт- } \\
\text { роль) }\end{array}$ & $\begin{array}{c}\text { пle } \\
\text { пакет }\end{array}$ & $\begin{array}{c}\text { ящик } \\
\text { (конт- } \\
\text { роль) }\end{array}$ & $\begin{array}{c}\text { пle } \\
\text { пакет }\end{array}$ \\
\hline \multicolumn{13}{|c|}{10 діб } \\
\hline Стандартні, \% & 85,4 & 90,0 & 64,8 & 96,6 & 86,7 & 92,2 & 35,8 & 53,8 & 86,8 & 78,0 & 74,0 & 92,0 \\
\hline Нестандартні, \% & 7,5 & 7,1 & 13,2 & 3,0 & 11,5 & 6,5 & 32,2 & 13,2 & 10,3 & 11,5 & 24,8 & 7,7 \\
\hline Хворі, \% & 1,9 & 1,4 & 17,5 & - & - & 1,5 & 41,5 & 58,6 & - & 10,3 & - & - \\
\hline $\begin{array}{c}\text { Природні втрати } \\
\text { маси, \% }\end{array}$ & 5,2 & 1,5 & 4,5 & 0,4 & 1,9 & 1,3 & 8,4 & 7,3 & 2,9 & 0,2 & 1,4 & 0,5 \\
\hline \multicolumn{13}{|c|}{20 діб } \\
\hline Стандартні, \% & 86,9 & 70,0 & 36,3 & 78,7 & 79,0 & 77,9 & \multirow{4}{*}{\multicolumn{2}{|c|}{-}} & 72,4 & 53,1 & 56,2 & 63,6 \\
\hline Нестандартні, \% & 5,6 & 20,1 & 40,5 & 12,6 & 8,3 & - & & & 5,3 & 33,7 & 29,2 & 30,3 \\
\hline Хворі, \% & 1,5 & 3,3 & 15,6 & 4,4 & - & 6,1 & & & 6,2 & 9,9 & 3,0 & 2,0 \\
\hline $\begin{array}{c}\text { Природні втрати } \\
\text { маси, \% }\end{array}$ & 6,0 & 6,6 & 7,6 & 4,3 & 12,7 & 16,0 & & & 16,1 & 3,3 & 11,6 & 4,1 \\
\hline
\end{tabular}


СІЛЬСЬКЕ ГОСПОДАРСТВО. РОСЛИННИЦТВО

\begin{tabular}{|c|c|c|c|c|c|c|c|c|c|c|c|c|c|c|c|c|}
\hline \multirow[b]{4}{*}{ Сорт } & \multirow{2}{*}{\multicolumn{8}{|c|}{$\begin{array}{r}\text { 2. Динаміка хімічних no } \\
\text { за різними умовами та в різ } \\
\text { Овочесховище }\end{array}$}} & \multicolumn{8}{|c|}{$\begin{array}{l}\text { лодів баклажсана } \\
\text { дн за 2009-2010 рр.) }\end{array}$} \\
\hline & & & & & & & & & & & Хол & ІЛ & на ка & nepa & & \\
\hline & \multicolumn{4}{|c|}{$\begin{array}{c}\text { дерев'яний ящик } \\
\text { (контроль) }\end{array}$} & \multicolumn{4}{|c|}{$\begin{array}{c}\text { перфорований } \\
\text { поліетиленовий пакет }\end{array}$} & \multicolumn{4}{|c|}{$\begin{array}{c}\text { дерев'яний ящик } \\
\text { (контроль) }\end{array}$} & \multicolumn{4}{|c|}{$\begin{array}{c}\text { перфорований } \\
\text { поліетиленовий пакет }\end{array}$} \\
\hline & 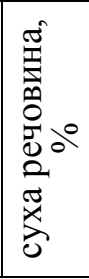 & 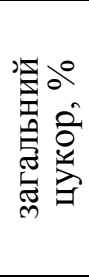 & 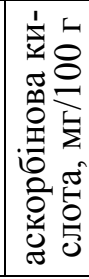 & 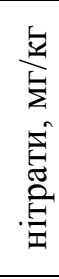 & 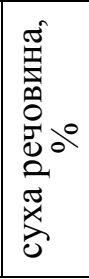 & 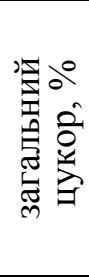 & 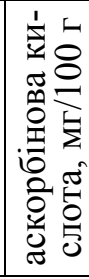 & 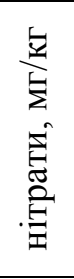 & 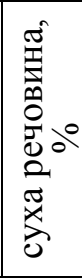 & 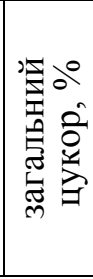 & 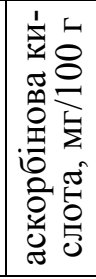 & 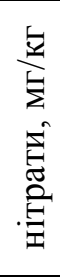 & 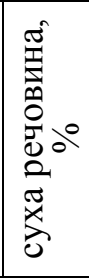 & 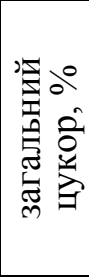 & 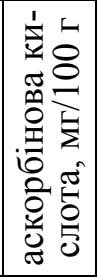 & 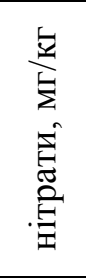 \\
\hline \multicolumn{17}{|c|}{ До зберігання } \\
\hline Ал & 92 & 2,84 & 2,77 & 5 & 92 & 2,84 & 2,77 & 45 & 8,92 & 2,84 & 2,77 & 45 & 92 & 2,84 & 2,77 & 45 \\
\hline & ,91 & 2,97 & 2,73 & 68 & 9,91 & 2,97 & 2,73 & 68 & 9,91 & 2,97 & 2,73 & 68 & 9,91 & 2,97 & 2,73 & 68 \\
\hline & & 84 & 2,36 & 3 & 9 & 84 & 2,36 & 31 & 9 & 84 & 2,36 & 57 & 49 & 2,84 & 2,36 & 57 \\
\hline \multicolumn{17}{|c|}{10 діб } \\
\hline Алмаз & 50 & 2,62 & 2,50 & 31 & 8,79 & 2,62 & 2,70 & 48 & 8,90 & 2,55 & 3,30 & 24 & 8,89 & 2,84 & 2,96 & 34 \\
\hline $\begin{array}{l}\text { Біла } \\
\text { Лілія }\end{array}$ & $\underline{9,79}$ & 2,87 & 2,68 & 21 & 8,72 & 2,89 & 2,51 & 26 & 9,39 & 2,77 & 3,29 & 38 & 8,64 & 2,84 & 3,06 & 39 \\
\hline Сауран & 9,28 & 63 & 2,51 & 44 & 9,06 & 2,74 & 2,23 & 62 & 9,48 & 2,78 & 4,4 & S & 81 & 2,76 & 3,46 & 55 \\
\hline \multicolumn{17}{|c|}{20 діб } \\
\hline & 8,13 & 2,59 & 2,42 & J & 8,68 & 2,61 & 2,66 & 57 & 82 & 2,48 & 2,74 & 61 & 64 & 2,77 & 2,45 & 84 \\
\hline $\begin{array}{l}\text { Біла } \\
\text { Лілія }\end{array}$ & 9,73 & 2,68 & 2,6 & 79 & 8,63 & 74 & 2,45 & 83 & \multicolumn{4}{|c|}{ 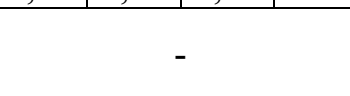 } & \\
\hline Сауран & 9,28 & 2,43 & 2,70 & 69 & 9,09 & 2,63 & 2,13 & 49 & 9,35 & 2,53 & 3,69 & 54 & 8,32 & 2,41 & 2,84 & 57 \\
\hline
\end{tabular}

Високий вміст сухих речовин був в сорті Біла Лілія у варіанті овочесховище - дерев'яний ящик $(9,79 \%)$, більший вміст загального цукру також у сорті Біла Лілія у варіанті овочесховище - перфорований поліетиленовий пакет (2,89 \%).

Подібна тенденція щодо втрати сухих речовин, загального цукру спостерігалась і після двадцяти діб зберігання. Високий вміст збереження сухих речовин відмічався у плодах сорту Сауран у варіанті «холодильна камера - дерев'яний ящик» $(9,35 \%)$, загального цукру в сорті Біла Лілія у варіанті «овочесховище - перфорований поліетиленовий пакет» $(2,74$ \%). Зберігання сорту Біла Лілія в умовах холодильної камери понад 10 діб є неможливим, тому визначення хімічних показників у плодах даного сорту не проводилося.

Таким чином, зберігання плодів баклажана сортів Алмаз та Сауран у перфорованих поліетиленових пакетах в умовах холодильної камери дає змогу зберегти їх товарний вигляд без

\section{БІБЛІОГРАФІЯ}

1. ДСТУ 2660-94 Баклажани свіжі. - Технічні умови. - К.: Держстандарт України, 1994. - 10 с. 2. Книга-каталог сорти і гібриди овочевих та баштанних культур / Т. К. Горова, Л. Є. Плужнікова, М. О. Скляревський [та ін.]. - Х., 2003. - 44 с. ознак в'янення і псування 3 мінімальними втратами хімічних показників протягом двадцяти діб, окрім біло-плідного сорту Біла Лілія, який $є$ абсолютно не придатним для зберігання в умовах холодильної камери.

Подальше зберігання плодів баклажана дослідних сортів більше двадцяти діб недоцільне через значні втрати маси (16-21\%) і різкі зміни хімічного складу плодів.

Висновки. Протягом 10-20 діб плоди баклажана західно-азіатського (сорт Алмаз) та східноазіатського (сорт Сауран) підвидів найбільш доцільно зберігати у холодильній камері за температури $+3 \ldots+4{ }^{\circ} \mathrm{C}$, використовуючи для пакування перфорований поліетиленовий пакет. Для зберігання плодів білого кольору (сорт Біла Лілія - західно-азіатський підвид) потрібно використовувати дерев'яні ящики, розміщуючи їх в овочесховищі 3 природною вентиляцією.

3. Магомедов P. K. Научно-практические основы транспортирования и хранения скоропортящихся овощей / Р. К. Магомедов. - М.: ФГНУ «Росинформагротех», 2004. - 200 c. 